Vol. 18 (2009): 440-459.

\title{
An integrated simulation model to evaluate national measures for the abatement of agricultural nutrients in the Baltic Sea
}

Kari Hyytiäinen*, Heini Ahtiainen, Jaakko Heikkilä, Janne Helin, Anni Huhtala, Antti Iho, Kauko Koikkalainen, Antti Miettinen, Eija Pouta and Janne Vesterinen

MTT Economic Research, Luutnantintie 13, FI-00410 Helsinki, Finland,

*email: firstname.lastname@mtt.fi

This study introduces a prototype model for evaluating measures to abate agricultural nutrients in the Baltic Sea from a Finnish national perspective. The stochastic simulation model integrates nutrient dynamics of nitrogen and phosphorus in the sea basins adjoining the Finnish coast, nutrient loads from land and other sources, benefits from nutrient abatement (in the form of recreation and other ecosystem services) and the costs of agricultural abatement activities. The aim of the study is to present the overall structure of the model and to demonstrate its potential using preliminary parameters. The model is made flexible for further improvements in all of its ecological and economic components. The results of a sensitivity analysis suggest that investments in reducing the nutrient load from arable land in Finland would become profitable only if the neighboring countries in the northern Baltic committed themselves to similar reductions. Environmental investments for improving water quality yield the highest returns for the Bothnian Bay and the Gulf of Finland, with smaller returns for the Bothnian Sea. Somewhat surprisingly, in the Bothnian Bay the abatement activities become profitable from the national viewpoint, because the riverine loads from Finland represent a high proportion of the total nutrient loads. In the Gulf of Finland, this proportion is low, but the size of the coastal population benefiting from improved water quality is high.

Key-words: cost-benefit analysis, nutrient abatement, Monte Carlo simulation, recreation, valuation 
Vol. 18 (2009): 440-459.

\section{Introduction}

The Baltic Sea suffers from eutrophication caused by elevated nutrient concentrations. These are driven by external nutrient loads and internal nutrient recycling. External nutrient loads are strongly linked to current economic activities. Agriculture, municipalities, industry, and society as a whole use the Baltic Sea as a rent-free nutrient sink, deteriorating its water quality. This causes economic losses, as recreational values diminish (Egan et al. 2009, Markowska and Zylicz 1999, Soutukorva 2005, Toivonen et al. 2004), the operational environment of fisheries is impaired (Lappalainen 2002), biodiversity is lost (Beaumont et al. 2007, Worm et al. 2006), and the non-use value people place on the sea decreases (Turner et al. 1999). The situation is an example of a market failure: even though the economic benefits of enhancing water quality outweigh the costs, the markets have failed to provide the correct incentives to polluting firms or nations and the sea remains highly polluted.

Recently, an increasing body of economic research has highlighted such market failures and suggested corrective measures. Perhaps the most prominent study is The Stern Review on the Economics of Climate Change (Stern 2007), which analyzes the global economic costs and benefits of $\mathrm{CO}_{2}$ policies in the long term. Similar analyses combining economic and ecological models have been conducted for the Baltic Sea area. The studies have estimated least-cost solutions for reaching nutrient abatement targets using a given set of measures (Byström 2000, Brady 2003) or reaching a given overall abatement level by allocation efforts between sectors and countries (Gren 2001, Ollikainen and Honkatukia 2001, Elofsson 2003). Some economic studies have used a dynamic approach for a particular sub-basin (Hart and Brady 2002, Laukkanen and Huhtala 2008). Gren et al. (2000) analyze cost-effective management of coastal nutrient load and acknowledge the role of stochastics in pollutant transport. Gren (2008) compares mitigation and adaptation strategies against water pollution using stochastic programming and Gren et al. (2009) apply a cost-effectiveness analysis to assess the value of mussel farming for nutrient cleaning in the Baltic Sea. Pitkänen et al. (2007) combine the outcomes from a dynamic basin model and a biogeochemical model with high temporal and spatial resolution. A major effort in Baltic Sea research is the construction of the Mare-Nest decision support system (Baltic Nest Institute 2008, see also Wulff et al. 2001, Savchuk and Wulff 2007, 2009). However, none of these studies has truly combined all three essential elements of the tragedy of the Baltic Sea: the stochastic development of water quality and the underlying ecological processes, the relevant economic activities in the sea basin and its watershed area, and the economic benefits to be gained from the improved quality of sea amenities.

We introduce a model which, on the one hand, covers the three major elements at the outset and, on the other, is flexible enough to allow for further improvements in both its ecological and economic components. We illustrate the properties of the model by using it to evaluate nutrient abatement measures in Finnish agriculture. In the model, the riverine nutrient loads are modeled as stochastic inputs for the three sea basins adjoining Finland. The level of nutrient concentration of the next period in a given sea basin is determined by the concentration of the current period and nutrient inputs and outputs between various sources and sinks, examples being air, sediment processes and exchange of water with adjacent sea basins. The analysis is limited to marine areas along the Finnish coast and to the effects of eutrophication and abatement activities on the country's economy. The model is distinctly policy-oriented and currently focuses on nutrient abatement in agriculture, which is the principal source of nutrient loads in Finland.

The Helcom Baltic Sea Action Plan (2007) includes country targets and basin targets for nutrient abatement. Yet, there is no binding international agreement that would force the sovereign Baltic Sea countries to commit to any nutrient reductions. Thus, each country acts on its self-interest when deciding on how much to invest in nutrient abatement. This paper focuses on evaluating the economic efficiency of national nutrient abatement decisions; however, given the international nature 
Hyytiäinen, K. et al. An integrated simulation model for agricultural nutrient abatement

of the common property problem, we also illustrate how joint efforts between neighboring countries may affect the profitability of national investments in abatement.

The aim of this paper is to present the structure of the model and to demonstrate its potential using preliminary parameters. The test simulations are carried out for four alternative target levels of nutrient abatement $(16 \%$ and $30 \%$ reductions in agricultural loads of nitrogen and phosphorus) in order to tentatively evaluate the profitability of environmental investment on water quality. A $30 \%$ reduction is selected to accord with the water protection targets set by the Finnish government for loads from arable land by 2015 (Finnish Government 2006). We also identify the most acute gaps in the model with a view to its further development. For example, the next step for future research might be to analyze the distributional effects of the damage from eutrophication across some or all of the Baltic Sea countries.

Our model applies cost-benefit analysis (CBA), which has not been used in Finland for evaluating environmental policies as intensively as in many other countries, such as, the UK and the US (Hanley 2001, Turner 2007). The alternative approaches in Finland thus far have been different types of participatory methods with stakeholder involvement, and cost-effectiveness analyses. These have not explicitly included the benefits of environmental improvements. The goals of the policy - the environmental quality to be achieved - have been found using the participatory or political processes and the researcher has been left to find the least expensive way to achieve these goals. Our case shows that integrating benefit measures into the analysis augments the participatory approach, as the benefits are derived from the preferences of the public. Our results on the welfare effects of abatement measures in the drainage basins of the Bothnian Bay and the Gulf of Finland, for instance, illustrate the strength and flexibility of the CBA approach.

The rest of the paper is organized as follows. The next section presents the structure of the simulation model and the data used in the modeling exercise. The third section presents the results from different model components and illustrates the steps needed to describe how the deterioration of the Baltic Sea leads to economic costs. The fourth section is devoted to identifying the caveats and most obvious gaps in our present knowledge with a view to developing either the current model further or other models suitable for policy analysis and evaluation.

\section{Materials and methods}

Our stochastic simulation model combines the ecological processes and economic consequences of eutrophication in the northern Baltic Sea. The model consists of four main components: 1) nutrient stock dynamics in the selected sea basins, 2) nutrient loads from land and other sources, 3 ) the costs of agricultural nutrient abatement and 4) the benefits of nutrient abatement to Finnish citizens. Riverine loads to the sea basins adjoining the Finnish coast and the nutrient concentrations in the Baltic Proper are described as stochastic processes. The benefits and costs of abatement are compared in a cost-benefit analysis. A simplified diagram of the model is presented in Figure 1.

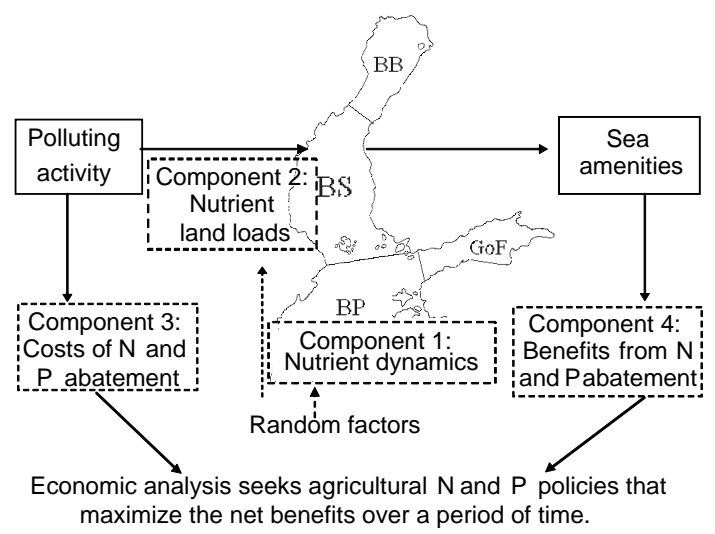

Fig. 1. Framework for the application of economic methods to the management of eutrophication 
Vol. 18 (2009): 440-459.

\section{Component 1: Description of nutrient dynamics} The areas of the Baltic Sea adjoining the Finnish coast are divided into three sea basins (i): the Bothnian Bay $(i=1)$; the Bothnian Sea, including the Archipelago Sea and the Sea of Åland $(i=2)$; and the Gulf of Finland $(i=3)$. The boundary at which these basins exchange water and nutrients with the Baltic Proper $(i=4)$ forms the southern limit of the area covered by the present model. The nutrient budgets of the basins are described as in Savchuk (2005). The two critical nutrients causing eutrophication are nitrogen $(\mathrm{N})$ and phosphorus $(\mathrm{P})$. The state variables of the model are $Q_{i, t}^{N}$ and $Q_{i, t}^{P}$, the amounts of total $\mathrm{N}$ and $\mathrm{P}$ (in tons). Time is denoted by $t=1, \ldots, 200$ and the time step is one year. The dynamics of the nutrient balances are described by:

$$
\begin{aligned}
& Q_{i, t+1}^{N}=Q_{i, t}^{N}+\sum_{j=1}^{n_{i}} L_{i, j, t}^{N} \\
& +A_{i}^{N}+\sum_{k=1}^{4}\left(W_{i, k}^{\text {out }} c_{i, t}^{N}-W_{i, k}^{\text {in }} c_{k, t}^{N}\right) \\
& -D_{i}-B_{i}+F_{i}, \quad i=1,2,3 \\
& Q_{i, t+1}^{P}=Q_{i, t}^{P}+\sum_{j=1}^{n_{i}} L_{i, j, t}^{P} \\
& +A_{i}^{P}+\sum_{k=1}^{4}\left(W_{i, k}^{\text {out }} c_{i, t}^{P}-W_{i, k}^{i n} c_{k, t}^{P}\right) \\
& -B_{i}+I_{i}, \quad i=1,2,3
\end{aligned}
$$

where $L_{i, j, t}^{N}$ and $L_{i, j, t}^{P}$ are the annual land loads, and $A_{i}^{N}$ and $A_{i}^{P}$ the atmospheric deposition of $N$ and $P$. The land loads are expressed for the three basins $(i=1,2,3)$ and $n_{i}$ countries accounting for the land load in each basin $\left(j=1, \ldots, n_{i}\right)$. Denitrification, burial, and $\mathrm{N}$ fixation by cyanobacteria are denoted by $D$, $B$, and $F$, respectively, and $I$ denotes the internal loading of $\mathrm{P}$ from sea bottom sediments.

The outflow of water from the $i^{\text {th }}$ to $k^{\text {th }}$ basin is denoted by $W_{i, k}^{\text {out }}$, and the inflow from the $k^{\text {th }}$ to $i^{\text {th }}$ basin by $W_{i, k}^{i n}$. The nutrient concentrations $c^{N}$ and $c^{P}$ are expressed in $\mu \mathrm{g}^{-1}$ and are obtained by dividing the quantity of nutrients (in tons) by the water volume (in $\mathrm{km}^{3}$ ) in each basin $i$ :

$$
c_{i, t}=\frac{Q_{i, t}}{V_{i}}, \quad i=1,2,3
$$

It is assumed that the nutrients are well mixed in each basin. All other nutrient flows except for land loads are assumed to remain constant over time. Thus, variation in the future developments of nutrient concentrations in the Gulf of Finland, Bothnian Bay and Bothnian Sea is a consequence of stochastic land loads for watersheds discharging their waters into these sea basins and annual variation in the nutrient concentrations in the Baltic Proper basin adjoining the study area. For the Baltic Proper, nutrient concentrations are predicted using a simpler equation that directly incorporates the effects of stochastic land loads and occasional salt pulses from the North Sea. The future developments of nutrient concentrations in the Baltic Proper are predicted by:

$c_{i, t}=c_{i, 1}\left[1+\alpha\left(1-e^{-\beta t}\right)\right\rfloor+c_{i, t} \sigma d z, \quad i=4$

where $\alpha$ and $\beta$ are parameters describing the future steady-state concentration level and the rate of change, respectively. The parameter $\sigma$ represents the coefficient of variation and $d z$ is a normally distributed random variable. All the parameter values are presented in Appendix 1.

\section{Component 2: Projecting nutrient land loads}

The second component of the model describes the future development of land loads, including nutrient leaching and runoff from arable land, forests and point sources. Annual variation in land loads is a special feature of non-point source pollution, and is explicitly taken into account in our model. To project future land loads, information is needed on (1) the probable development of the agricultural sector and other critical sectors by country and region and (2) the present level of and past fluctuations in land loads. Table 1 shows the past and probable future development of the agricultural sector in Finland. The information on past developments has been drawn from the Yearbook of Farm Statistics (1983, 1992/1993, 2000, 2007). The future developments of the agricultural sector are based on the results of the Finnish agricultural sector model DREMFIA (MMM 2008). The predictions on the average land loads after 20 and 50 years (Table 2 ) are based on the information in Table 1 and the fact that agriculture currently accounts for about $40 \%$ of the total land 
Hyytiäinen, K. et al. An integrated simulation model for agricultural nutrient abatement

Table 1. Past and predicted developments of the agricultural sector in Finland

\begin{tabular}{|c|c|c|c|c|c|c|c|c|}
\hline Indicator & $1950 \mathrm{~s}$ & $1960 \mathrm{~s}$ & $1970 \mathrm{~s}$ & $1980 \mathrm{~s}$ & 1990s & $2006 / 7$ & 2020s & 2050s \\
\hline Subsurface draining (1000 ha/yr) & 23 & 34 & 38 & 33 & 8 & 5 & 5 & 5 \\
\hline Clearing of arable land (1000 ha/yr) & & 10 & 4 & 7 & 7 & 7 & 12 & 9 \\
\hline Afforestation of arable land (1000 ha/yr) & & & 7 & 4 & 10 & 2 & 6 & 5 \\
\hline Total area of agricultural land (1000 ha) & 2462 & 2669 & 2589 & 2453 & 2222 & 2295 & 2410 & 2525 \\
\hline Meadows (1000 ha) & & 153 & 146 & 138 & 25 & 34 & 35 & 35 \\
\hline Yield of barley (kg/ha) & 1650 & 1980 & 2570 & 3150 & 2700 & 3500 & 4000 & 4500 \\
\hline Fallows and cultivated arable land (1000 ha) & & 249 & 290 & 401 & 720 & $230^{\mathrm{a}}$ & 390 & 290 \\
\hline Artificial fertilization of $\mathrm{N}(\mathrm{kg} / \mathrm{ha})$ & & 69 & 83 & 111 & 84 & 74 & 86 & 74 \\
\hline Artificial fertilization of $\mathrm{P}(\mathrm{kg} / \mathrm{ha})$ & & 31 & 28 & 30 & 10 & 8 & 5 & 5 \\
\hline Silage/hay (1000 ha) & & 1050 & 943 & 682 & 664 & 654 & 650 & 700 \\
\hline No. of cows $(1000)$ & 1200 & 1000 & 730 & 490 & 370 & 309 & 230 & 240 \\
\hline No. of farms (1000) & & 297 & 229 & 129 & 88 & 69 & 48 & 25 \\
\hline Average farm area (ha) & 8 & 10 & 12 & 17 & 26 & 33 & 50 & 100 \\
\hline No. of dairy farms (1000) & 243 & 210 & 98 & 48 & 24 & 15 & 6 & 2 \\
\hline No. of estates on grain cultivation (1000) & & 80 & 112 & 47 & 41 & 41 & 36 & 15 \\
\hline Lime for soil improvement $(\mathrm{kg} / \mathrm{ha})$ & 122 & 150 & 193 & 488 & 376 & 303 & 400 & 450 \\
\hline Use of pesticides (g/ha) & & & & 850 & 500 & 650 & 700 & 700 \\
\hline No. of tractors $(1000)$ & & & 234 & 208 & 170 & 175 & 150 & 100 \\
\hline No. of horses (1000) & 300 & 92 & 32 & 42 & 56 & 66 & 82 & 82 \\
\hline No. of pigs (1000) & & 600 & 1000 & 1500 & 1300 & 1400 & 1200 & 1200 \\
\hline
\end{tabular}

${ }^{\mathrm{a}}$ set-aside fields that are not entitled to agricultural support (about 100,000-150,000 ha) are not included

Table 2. Mean land loads of nutrients at present and after 20 and 50 years

\begin{tabular}{lrrrrrrr}
\hline \multirow{2}{*}{ Nutrient source } & \multicolumn{3}{c}{ Total P (tons/yr) } & & \multicolumn{3}{c}{ Total N (tons/yr) } \\
\cline { 2 - 3 } \cline { 6 - 8 } & 2008 & 2028 & 2058 & & 2008 & 2028 & 2058 \\
\hline Rivers from Sweden to Bothnian Bay & 1104 & 950 & 900 & 19273 & 20000 & 19000 \\
Rivers from Finland to Bothnian Bay & 1805 & 1600 & 1400 & 29326 & 33000 & 30000 \\
Rivers from Finland to Bothnian Sea & 1550 & 1500 & 1800 & 24716 & 35000 & 33000 \\
Rivers from Sweden to Bothnian Sea & 1232 & 900 & 880 & 30278 & 23500 & 23000 \\
Rivers from Finland to Gulf of Finland & 605 & 600 & 450 & 13091 & 12000 & 11500 \\
Rivers from Russia to Gulf of Finland & 4174 & 5500 & 7000 & 76733 & 85000 & 90000 \\
Rivers from Estonia to Gulf of Finland & 779 & 1000 & 1150 & 18210 & 20000 & 21000 \\
\hline
\end{tabular}

loads in Finland. The predictions for other countries are based on the literature and expert opinions.

In Finland, an increase in the total land area used for farming, increased use of inorganic $\mathrm{N}$ fertilization and an increased rate of clearing arable lands will lead to increased $\mathrm{N}$ loads over the next 20 years. The loads are assumed to gradually decrease thereafter. The flow of total P from the Finnish rivers is assumed to decrease due to reduced use of inorganic fertilizers and gradually decreas- 
Vol. 18 (2009): 440-459.

ing P stocks in agricultural land. For the Bothnian Sea, however, the P loads will increase towards 2058 due to intensified poultry and pig farming and increased application of manure fertilization in southwest Finland.

In Sweden, nutrient loads are assumed to decrease over time as farmers adapt to the current agricultural policies (Kadin 2009). In Estonia, reintroducing arable land to agricultural production is assumed to increase the nutrient loads over the next 50 years (Statistics Estonia 2008). In Russia, plans to increase local animal production in the Leningrad Oblast and the ongoing practice of spreading the oversupply of manure on unmanaged fields explain the projected increase in land loads of $\mathrm{P}$ and $\mathrm{N}$ (Government of the Russian Federation 2007).
Table 3 shows historical data on riverine loads of total N and P flowing into the Baltic Sea for the period 1986-2000. There are large annual fluctuations in the land loads, mainly due to variations in weather conditions. The seasonal distribution and, in particular, total amount of rainfall are important determinants of nutrient runoff (Turtola and Paajanen 1995). It is assumed that the initial average land loads (in 2008) are the same as the average from the time series. Moreover, the standard deviations of land loads are assumed to remain the same in the future. The land loads for the following 200year period are predicted by the equation:

$$
L=D \gamma+S A Z \text {, }
$$
where $L$ is a $(14 \times 200)$ matrix for annual $\mathrm{N}$ and $\mathrm{P}$ loads for seven clusters of rivers for the next 200-

Table 3. Statistical data on land loads of total nitrogen and phosphorus (tons $\mathrm{yr}^{-1}$ )

\begin{tabular}{|c|c|c|c|c|c|c|c|c|c|c|c|c|c|c|}
\hline & \multicolumn{7}{|c|}{ Nitrogen } & \multicolumn{7}{|c|}{ Phosphorus } \\
\hline & \multicolumn{2}{|c|}{ Bothnian Bay } & \multicolumn{2}{|c|}{ Bothnian Sea } & \multicolumn{3}{|c|}{ Gulf of Finland } & \multicolumn{2}{|c|}{ Bothnian Bay } & \multicolumn{2}{|c|}{ Bothnian Sea } & \multicolumn{3}{|c|}{ Gulf of Finland } \\
\hline & Sweden & Finland & Finland & Sweden & Finland & Russia & Estonia & Sweden & Finland & Finland & Sweden & Finland & Russia E & Estonia \\
\hline & $y=1$ & $y=2$ & $y=3$ & $y=4$ & $y=5$ & $y=6$ & $y=7$ & $y=8$ & $y=9$ & $y=10$ & $y=11$ & $y=12$ & $y=13$ & $y=14$ \\
\hline 1986 & 17610 & 28865 & 27463 & 31297 & 13229 & 104135 & 29414 & 1106 & 1672 & 1668 & 1255 & 703 & 4301 & 507 \\
\hline 1987 & 18514 & 28683 & 20274 & 33908 & 14331 & 109897 & 31345 & 1142 & 2073 & 1417 & 1540 & 658 & 2824 & 753 \\
\hline 1988 & 16764 & 27771 & 28776 & 26351 & 15556 & 84847 & 17273 & 1060 & 1676 & 1870 & 1253 & 679 & 5007 & 984 \\
\hline 1989 & 17106 & 31830 & 23656 & 27147 & 14931 & 54565 & 13730 & 1416 & 2185 & 1402 & 1264 & 646 & 3414 & 812 \\
\hline 1990 & 15219 & 19399 & 29847 & 27065 & 15149 & 69524 & 19326 & 822 & 1250 & 1675 & 1134 & 571 & 3893 & 801 \\
\hline 1991 & 17652 & 29807 & 24378 & 25645 & 13592 & 77610 & 18479 & 990 & 1830 & 1496 & 1183 & 607 & 4239 & 697 \\
\hline 1992 & 19325 & 38644 & 28222 & 29412 & 15408 & 82906 & 19110 & 1157 & 2336 & 1490 & 1132 & 664 & 4282 & 696 \\
\hline 1993 & 19808 & 28727 & 19333 & 34830 & 10653 & 71516 & 16325 & 1227 & 2091 & 1137 & 1510 & 529 & 4971 & 614 \\
\hline 1994 & 15212 & 22428 & 19188 & 23382 & 11261 & 74242 & 13692 & 908 & 1592 & 1208 & 962 & 606 & 3976 & 979 \\
\hline 1995 & 19463 & 26029 & 22463 & 33686 & 12519 & 80358 & 15490 & 1154 & 1642 & 1330 & 1335 & 567 & 4239 & 843 \\
\hline 1996 & 17644 & 23488 & 19937 & 21539 & 11566 & 63932 & 11556 & 641 & 1221 & 1223 & 580 & 582 & 4073 & 480 \\
\hline 1997 & 18733 & 25655 & 20590 & 26460 & 8968 & 63752 & 13200 & 1458 & 1541 & 1107 & 1107 & 428 & 4140 & 647 \\
\hline 1998 & 27049 & 39461 & 26790 & 43643 & 13296 & 69860 & 22260 & 1232 & 2210 & 1479 & 1206 & 648 & 4353 & 891 \\
\hline 1999 & 21636 & 26374 & 24451 & 27771 & 12021 & 75924 & 18227 & 924 & 1551 & 1599 & 1380 & 562 & 4640 & 1324 \\
\hline 2000 & 27366 & 42726 & 35375 & 42042 & 13885 & 67931 & 13720 & 1328 & 2199 & 3144 & 1637 & 621 & 4261 & 662 \\
\hline mean & 19273 & 29326 & 24716 & 30278 & 13091 & 76733 & 18210 & 1104 & 1805 & 1550 & 1232 & 605 & 4174 & 779 \\
\hline STD & 3632 & 6504 & 4676 & 6359 & 1920 & 14646 & 5722 & 222 & 357 & 490 & 255 & 69 & 545 & 213 \\
\hline
\end{tabular}

Source: Baltic Nest Institute 2008 
Hyytiäinen, K. et al. An integrated simulation model for agricultural nutrient abatement

year period. The trend for the mean land loads is predicted by $D \gamma ; \gamma$ denotes a matrix of land loads interpolated from the values in Table 2 for the first 50 years and it is assumed that the mean loads remain the same thereafter. $D$ is a $(14 \times 14)$ diagonal matrix expressing the effects of nutrient abatement on annual mean loads. Without nutrient abatement, $D$ is an identity matrix. With nutrient abatement, the elements of the diagonal are obtained by multiplying the proportion of total land loads attributable to agriculture, $\tau_{y}$, by the level of nutrient reduction $\varnothing_{y}$ or each of the seven river clusters and for both $\mathrm{N}$ and $\mathrm{P}$ (i.e. there are 14 nutrient- and river-specific sources of agricultural land load, denoted by $y$ ):

$D_{y, y}=1-\varnothing_{y} \tau_{y}, y=1, \ldots, 14$
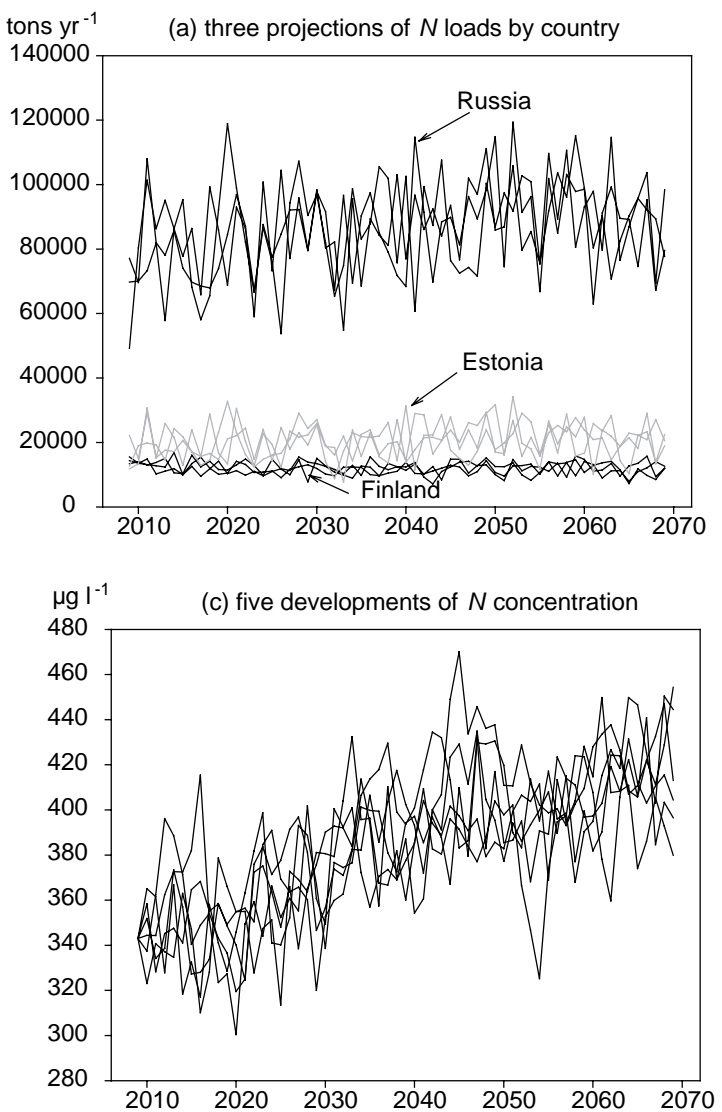

In the second part of equation [5], describing the random deviations around the mean, $S$ is a diagonal matrix for the standard deviations of past land loads in the diagonal, $A$ is the Cholesky decomposition (matrix square root) of the variance-covariance matrix of the standardized past land loads (see e.g. Fishman 1995, p. 223), and $Z$ is a matrix of normally distributed random variables. The past land loads are spatially correlated and it is assumed that the annual loads will covariate in a similar manner in the future (cf. Elofsson 2003). Historical data on land loads (Table 3 ) were standardized by subtracting from each observation the average land load and dividing the difference by the standard deviation. Figure 2 presents sample projections of land loads and developments in nutrient concentrations.
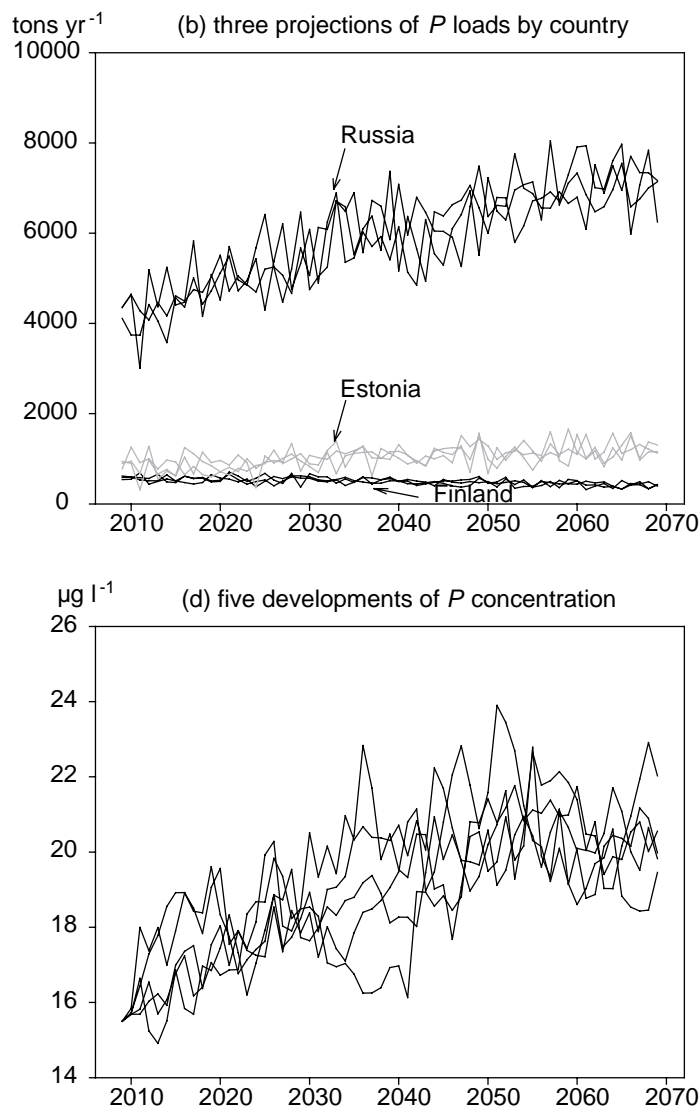

Fig. 2. Baseline projections of land loads and developments of nutrient concentrations over the next 60 years in the Gulf of Finland. 
Vol. 18 (2009): 440-459.

Variation in land loads is a consequence of variation in annual weather conditions (amount and temporal distribution of rainfall in particular). The variation in nutrient concentrations is a consequence of stochastic land loads, the exchange of water between adjacent basins and the development of nutrient concentrations in the Baltic Proper.

\section{Component 3: Costs of nutrient abatement}

The set of abatement measures consists of reductions in nutrient fertilization, changes in cultivated crops and cultivation methods, reductions in the number of dairy cattle, changes in the cattle diet, and the allocation of set-aside land. The abatement costs are derived from a static deterministic non-linear economic watershed model that provides profitmaximizing solutions for representative dairy and cereal farms (Helin 2009). The abatement cost curve for each farm type is calculated as the difference between unconstrained and constrained optimal profits and for $\mathrm{N}$ and $\mathrm{P}$ load constraints separately. Thus, we obtain the cost-efficient combination of abatement measures for each nutrient and for each farm type. The distribution of arable land between the farm types is assumed to be fixed. The economic parameters, such as prices and subsidies, are for the year 2007, and the abatement cost is assumed to be the same for all watersheds of the three sea basins adjacent to the Finnish coast.

The abatement measures $(h)$ include reductions of nutrients from the agricultural sector represented by the two farm types. In addition to the baseline $(h=1)$, where no abatement is implemented, we consider measures that obtain cost-efficient nutrient reductions of $30 \%$ and $16 \%$ for either $\mathrm{N}(h=2,3)$ or P $(h=4,5)$. Each measure has an endogenously determined cross-over reduction effect on the other nutrient. The efficient distribution of abatement measures between the farm types is determined by the abatement cost curves for each nutrient. The resulting unit costs of nutrient abatement measures, c_abat ${ }_{h}$, are expressed as the average cost of reducing $1 \mathrm{~kg}$ of either $\mathrm{N}$ or $\mathrm{P}$ independently of the future developments of the agricultural sector. The unit cost is assumed to remain constant over time. The net present value of the costs of a given abatement measure, $C_{h}$, is approximated by multiplying the unit cost by total nutrient reductions for the Finnish rivers and dividing the product by the rate of interest. The equations for $\mathrm{N}$ and $\mathrm{P}$ are

$$
C_{h}=\frac{C_{-} a b a t_{h}\left[\gamma_{2,1}\left(1-D_{2,2}\right)+\gamma_{3,1}\left(1-D_{3,3}\right)+\gamma_{7,1}\left(1-D_{7,7}\right)\right]}{r}, h=2,3
$$

and

$$
\begin{aligned}
& C_{h}= \\
& \frac{c_{\_} a b a t_{h}\left[\gamma_{9,1}\left(1-D_{9,9}\right)+\gamma_{10,1}\left(1-D_{10,10}\right)+\gamma_{14,1}\left(1-D_{14,14}\right)\right]}{r}, h=4,5
\end{aligned}
$$

respectively. The description of the environmental effects of different abatement activities in the economic watershed model (Helin 2009) is based on a meta-modeling of the Finnish nutrient process model ICECREAM (Helin et al. 2006, Rekolainen and Posch 1993). The total P load is given as a function of annual runoff, erosion, fertilization and $\mathrm{P}$ stock, while $\mathrm{N}$ depends more directly on the annual fertilization levels (Uusitalo and Jansson 2002, Uusitalo et al. 2003, Simmelsgaard and Djurhuus 1998). We use the mean weather parameters for the watershed of the Kalajoki River in 1996-2007 and assume a mean slope of $1 \%$ and mixed soil composition. The nutrient-specific abatement measures and their effects on the non-targeted nutrient are shown in Appendix 1 together with the associated parameter values.

\section{Component 4: Benefits of nutrient abatement}

As eutrophication causes damage to the ecosystem, abatement measures reducing this damage increase human well-being. Assessing the monetary value of the benefits of nutrient abatement in the Baltic marine ecosystem is difficult and, for some elements, impossible. Some of the total benefits, such as improved ecosystem services contributing to human well-being, can, however, be estimated. We use two valuation approaches to describe the benefits (the damage) from decreased (increased) eutrophication: the travel cost method and meta-analysis. The travel cost method is applied here to capture the value of functioning ecosystem services by the expenditures people make on coastal water-related recreation. The meta-analysis we draw on summarizes the results of previous valuation studies on the Baltic Sea to 
Hyytiäinen, K. et al. An integrated simulation model for agricultural nutrient abatement

provide an estimate for marine-related amenities. Using two types of valuation methods provides a broader perspective on the reliability of the estimates and enables comparisons between the approaches, a rare opportunity in a cost-benefit analysis.

In contrast to the travel cost method, which analyzes only use values through recreational demand, the meta-analysis includes the non-use values that people place on having a clean and healthy Baltic Sea. Thus, the meta-analysis will indicate somewhat higher values for changes in eutrophication. The two functions also differ in form (Fig. 3 ), which has a considerable effect on the results. The value functions describe the benefits (damage) in monetary terms as eutrophication decreases (increases) from its current level. The value functions presented in Figure 3 are formed by fitting equations to the value estimates calculated from the existing statistical models by Ahtiainen (2009) and Vesterinen et al. (2009). The points shown in Figures $3 \mathrm{a}$ and $3 \mathrm{~b}$ refer to the anchoring points that are used in the fitting process.

To estimate the value functions for the level of eutrophication we need to link the nutrient concentrations in the Baltic Sea to eutrophication and to human activities. Practice has shown that Secchi depth can be used as a reasonable proxy for eutrophication (Michael et al. 2000, Helcom 2007). The advantages of using water clarity as an indicator of eutrophication are its simplicity, both in terms of scientific measurement and the observational capability of the general public. On the other hand, water clarity is affected by factors other than eutrophication, and therefore does not correlate completely with eutrophication. We link water clarity to nutrient concentrations using a transfer function.

The data used to formulate the transfer function are those presented in Vesterinen et al. (2009), but the model used is slightly more detailed in that it takes the joint effect of nutrient concentration into account. The water quality data are taken from the PIVET (State of Finland's Surface Waters) database maintained by the Finnish Environment Institute. The data are from the summer months of the years 1998-2002 and 2004 and contain 16,787 quality measurements at a total of 1,487 points along the (a) Effect on water recreation (travel-cost method)

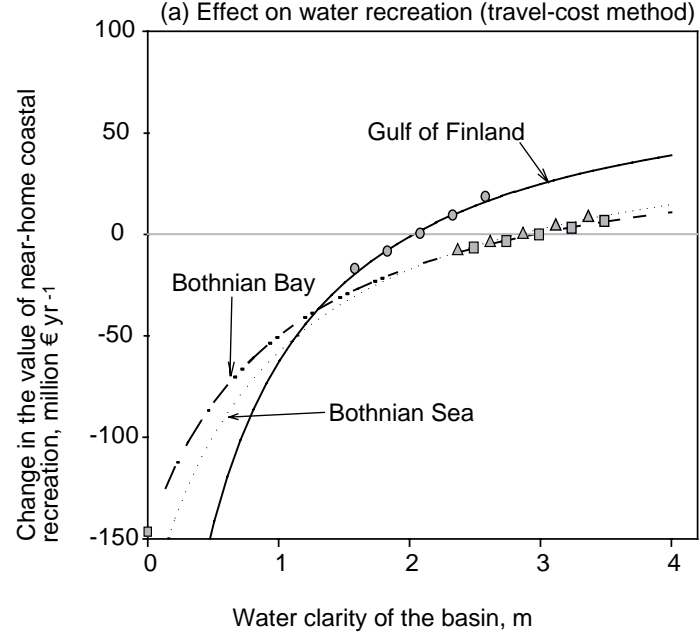

(b) Effect on use and non-use value (meta-analysis)

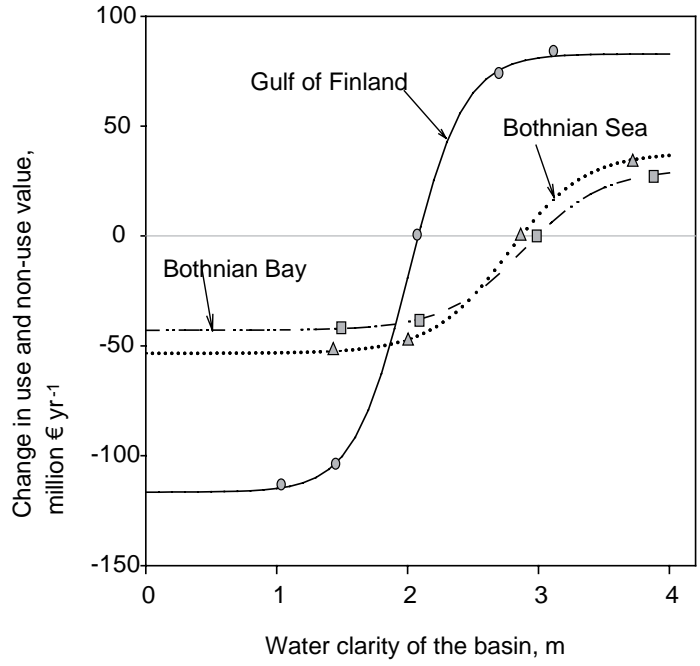

Fig. 3. The effect of altered water clarity

Finnish coast. The estimated transfer function to describe Secchi depth (sch) in meters is

$$
\begin{aligned}
& s c h_{i, h, t}=\eta_{i}+\kappa_{1, i} \ln \left(c_{i, h, t}^{P}\right)+\kappa_{2, i} \ln \left(c_{i, h, t}^{N}\right)+\kappa_{3, i} \frac{c_{i, h, t}^{N} c_{i, h, t}^{P}}{1000} \\
& +\kappa_{4, i} \text { temp }+\kappa_{5, i} \text { depth }, i=1,2,3, \forall h, t
\end{aligned}
$$

[9]

where $\eta_{i}$ and $\kappa_{1, i}, \ldots, \kappa_{5, i}$ are estimated parameter values. The water temperature and depth are denoted by 
Vol. 18 (2009): 440-459.

temp and depth, respectively. A II the variables were significant at $95 \%$ probability, except for temperature in the Bothnian Bay $(i=1)$. We chose the log-linear functional form as it provided the best fit to the data. Thus, the model is not an attempt to mimic natural nutrient-to-al gae dynamics, but rather a descriptive estimator of water clarity at the given nutrient concentration. The transfer function provides estimates using coastal water quality figures; however, we use basin-level nutrient concentrations in the study, thus making the implicit assumption that nutrient concentration changes are uniform across a basin, from the open sea to the coast. Figure 4 provides sample projections of average water clarity.

The results from the travel cost study of Vesterinen et al. (2009) are used to describe the value of recreational swimming, fishing and boating on the Baltic coast of Finland. The study estimates the effect of near-home water clarity on waterrelated recreation and the value of this recreation in Finland. The reported national aggregate value estimates are converted to basin-level estimates by using the relative proportion of the Finnish adult population living along the coast of each basin (totaling 2.15 million for the three basins). Furthermore, since the data suggest that $29 \%$ of water-related recreation occurs on inland waters of

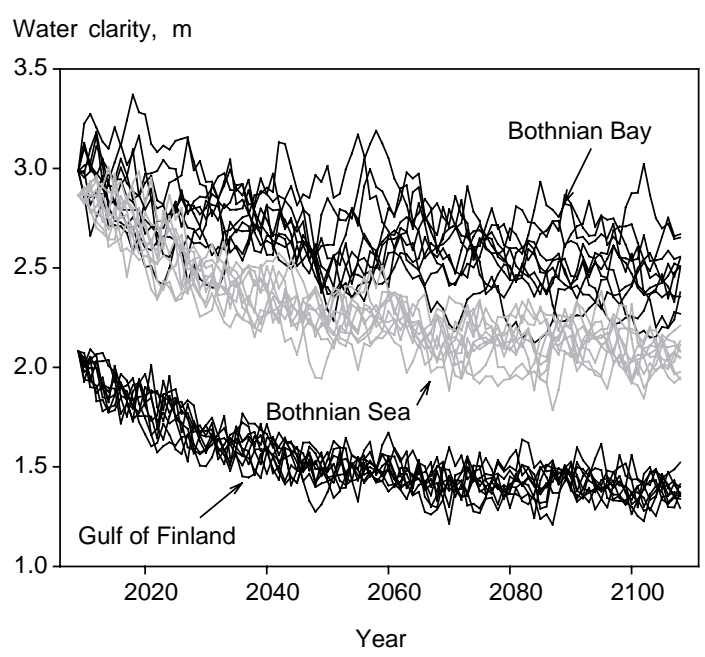

Fig. 4. Ten baseline projections for average water clarity in the three basins. coastal municipalities, we have subtracted the corresponding proportion from the number of people participating in coastal recreation. The resulting figure - the number of Finnish people affected by eutrophication in the Baltic Sea - is 1.53 million. Drawing a distinction between inland and coastal recreation entails an assumption that recreational behavior is identical among the coastal population and the population at large.

The results of the travel cost study indicate that near-home water clarity affects swimming and fishing behavior but not boating. A dditionally, the data from the study show that on virtually all coastal trips, different types of water recreation are engaged in on separate trips; for example, boating and fishing are reported as separate activities. Based on this result, we have combined the estimated values for all water-related recreation types in the value function (Fig. 3a).

The value function is formed by fitting a hyperbolic equation to the point estimates of the water quality effects on coastal recreational demand presented in Vesterinen et al. (2009). The anchoring points for the equation, shown as dots in Figure $3 \mathrm{a}$, are observations made $0.5 \mathrm{~m}$ above and below the present average water transparency in each basin. A t zero water transparency, we assume, based on the applied results, that swimming and fishing diminish to zero, while boating activity remains unchanged. The hyperbolic functional form thus forces the value function to be concave. The annual value of altered recreation possibilities is

$\mathrm{val}_{i, h, t}=\delta_{1, i}+\frac{\delta_{2, i} s_{i} h_{i, h, t}}{\delta_{3, i}+\operatorname{sch} h_{i, h, t}^{-}} \quad i=1,2,3, \forall h, t=1, \ldots, 200$

where $\delta_{1, i}, \delta_{2, i}, \delta_{3, i}$ are basin-specific parameters (see Appendix 1).

A $n$ al ternative approach for describing the effects of eutrophication is to construct the value function based on the estimates from a meta-analysis summarizing the findings of existing valuation studies on the benefits of protecting the Baltic Sea (Ahtiainen 2009). The meta-analysis enables prediction of the willingness to pay for specific proportional changes in water quality. Willingness to pay estimates are linked to changes in Secchi depth 
Hyytiäinen, K. et al. An integrated simulation model for agricultural nutrient abatement

by assuming that Secchi depth is an indicator of overall water quality.

The meta-analysis indicates higher willingness to pay to prevent losses in water quality than to make improvements in it, a phenomenon referred to as loss aversion (e.g. Kahneman et al. 1991, Tversky and Kahneman 1991). The value function is thus steeper in the domain where the Secchi depth indicates water quality that is inferior to the current level (Fig. 3b). Willingness to pay is assumed to be zero for a $0 \%$ change, and the fitted equation is anchored to observations for $30 \%$ and $50 \%$ changes in Secchi depth. In order to increase comparability with the travel cost results, the val ues are esti mated for changes that occur in a sea area and primarily affect recreational activities. The values based on the meta-analysis are estimated for both the adult coastal population ( 2.15 million) and for the total adult population in Finland (4.2 million).

The sigmoidal value function based on the meta-analysis is

$$
v a l_{i, h, t}=\vartheta_{1, i}+\frac{\vartheta_{2, i}}{\left.1+e^{\left(\left(s c h_{i h t}-\vartheta_{3 i}\right)\right.} \vartheta_{4 i}\right)}, i=1,2,3, \forall h, t
$$

where $\vartheta_{1, i}, \ldots, \vartheta_{4, i}$ are basin-specific parameters (Appendix 1).

The total benefits $(B)$ from improved water quality are obtained by discounting the differences in damage between "no abatement" and "abatement measure" over the first 200 years and assuming that the difference in annual damage remains the same thereafter:

$$
\begin{aligned}
& B_{h}= \\
& \sum_{i=1}^{200}\left(\operatorname{val}_{i, h, t}-\operatorname{val}_{i, 1, t}\right) e^{-r t}+\frac{\operatorname{val}_{i, h, 200}-\operatorname{val}_{i, 1,200}}{r} e^{-200 t} \\
& h=2, \ldots, 5
\end{aligned}
$$

Figure 5 provides sample paths for the development of abatement benefits in the Gulf of Finland.

Synthesis of components: Cost-benefit analysis The net present value is the relevant selection and ranking criterion of environmental projects in cases where there are no other investment outlets

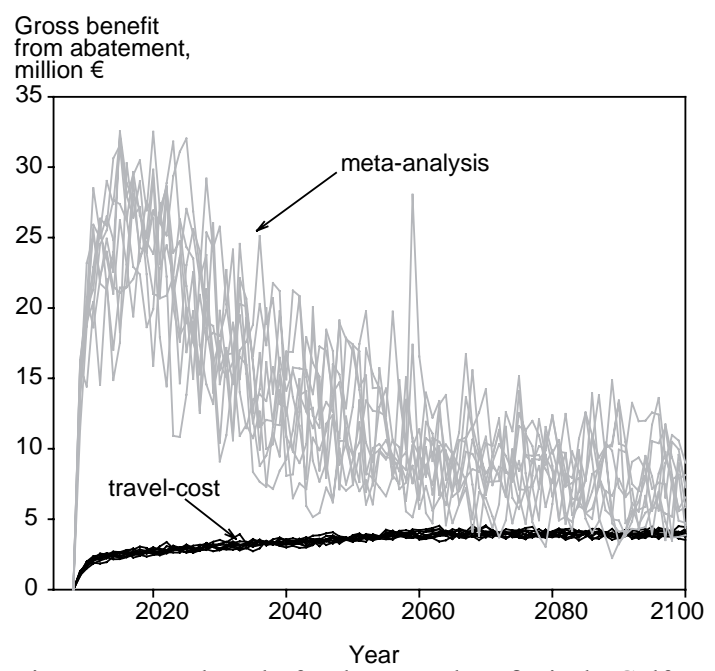

Fig. 5. Ten sample paths for abatement benefits in the Gulf of Finland for a 30\% reduction in P loads. Assumption: All countries in the northern Baltic Sea reduce nutrient loads in the same proportion.

competing for the same funds, that is, when the government can borrow any amount of money to finance an environmental project. In such a case, the magnitude of the projects being compared does not matter: the abatement measure yielding the highest expected net present value would be the rational choice for a risk-neutral social planner. Y et, the state budget may well be fixed, with projects in different sectors (e.g. health care, education, public transport) competing for limited funds, whereby the benefit-cost ratio may become an appropriate criterion for ranking alternative projects. The net present value (NPV) and benefit-cost ratio $(B C)$ of investing in water quality are obtained by

$N P V_{h}=B_{h}-C_{h}, h=2, \ldots, 5$

$B C_{h}=-\frac{B_{h}}{C_{h}}, h=2, \ldots, 5$.

Computation of the results comprises three steps. First, the time paths of damage are simulated for the baseline development and four alternative abatement measures in order to calculate NPVs 
Vol. 18 (2009): 440-459.

[13] and BCs [14] for a single random sample of land loads [5] and the development of nutrient concentrations in the Baltic Proper [4]. Second, these computations are repeated 500 times, each time drawing new sample paths of riverine loads and concentrations in the B altic Proper in order to establish an estimate for the probability distribution and expected values of NPVs and BCs. Third, a sensitivity analysis is conducted for the valuation method (travel cost [9] or meta-analysis [10]), population affected, rate of interest, level of international involvement in nutrient abatement and development of average nutrient concentrations in the B altic Proper [4]. The rates of interest cover a wide range, including the very low rate $(r=0.1 \%)$ which was applied in the Stern Review (Stern 2007). The discount rates used in evaluating public projects in
Finland are around 5\%, which is the default interest rate $(r=0.051)$ applied in our analysis.

\section{Results}

The expected NPVs and BCs for different abatement measures, rates of interest, valuation approaches, and levels of international involvement are shown in Table 4. The baseline simulations (the first nine rows in Table 4) assume that only Finland invests in nutrient abatement. The remaining computations assume that all the countries in the northern Baltic Sea (Finland, Sweden, Russia, and Estonia) agree to jointly reduce their nutrient loads in the same

Table 4. Cost-benefit analysis for different abatement measures, valuation approaches, rates of interest and international involvement.

\begin{tabular}{|c|c|c|c|c|c|c|c|c|}
\hline \multirow{2}{*}{$\begin{array}{l}\text { International } \\
\text { involvement }\end{array}$} & \multirow{2}{*}{$\begin{array}{l}\text { valuation } \\
\text { approach }\end{array}$} & \multirow[b]{2}{*}{$r$} & \multicolumn{3}{|c|}{ Expected NPV, million $€$} & \multicolumn{3}{|c|}{ Expected B/C-ratio } \\
\hline & & & N 16 & P30 & P16 & N 16 & P30 & P16 \\
\hline \multirow[t]{9}{*}{ Finland only } & Travel cost & $0.1 \%$ & -24365 & -12915 & -4116 & 0.04 & 0.17 & 0.26 \\
\hline & \multirow[t]{2}{*}{ coastal population } & $2.6 \%$ & -942 & -503 & -162 & 0.03 & 0.16 & 0.24 \\
\hline & & $5.1 \%$ & -482 & -261 & -85 & 0.03 & 0.14 & 0.22 \\
\hline & M eta-analysis & $0.1 \%$ & -23799 & -9767 & -2582 & 0.06 & 0.38 & 0.55 \\
\hline & \multirow[t]{2}{*}{ coastal population } & $2.6 \%$ & -882 & -275 & -44 & 0.09 & 0.54 & 0.79 \\
\hline & & $5.1 \%$ & -448 & -139 & -21 & 0.10 & 0.54 & 0.80 \\
\hline & M eta-analysis & $0.1 \%$ & -22319 & -4040 & 360 & 0.12 & 0.75 & 1.08 \\
\hline & \multirow[t]{2}{*}{ total population } & $2.6 \%$ & -795 & 29 & 116 & 0.18 & 1.05 & 1.55 \\
\hline & & $5.1 \%$ & -402 & 17 & 61 & 0.19 & 1.06 & 1.56 \\
\hline Finland, Sweden & Travel cost & $0.1 \%$ & -22201 & -7648 & -1223 & 0.12 & 0.51 & 0.78 \\
\hline \multirow[t]{8}{*}{ Russia, Estonia } & \multirow[t]{2}{*}{ coastal population } & $2.6 \%$ & -874 & -339 & -72 & 0.10 & 0.43 & 0.66 \\
\hline & & $5.1 \%$ & -452 & -189 & -46 & 0.09 & 0.38 & 0.58 \\
\hline & M eta-analysis & $0.1 \%$ & -21421 & -1796 & 1329 & 0.15 & 0.88 & 1.23 \\
\hline & \multirow[t]{2}{*}{ coastal population } & $2.6 \%$ & -705 & 203 & 203 & 0.28 & 1.34 & 1.96 \\
\hline & & $5.1 \%$ & -345 & 124 & 117 & 0.31 & 1.41 & 2.08 \\
\hline & M eta-analysis & $0.1 \%$ & -17643 & 11487 & 7974 & 0.30 & 1.73 & 2.42 \\
\hline & \multirow[t]{2}{*}{ total population } & $2.6 \%$ & -450 & 963 & 599 & 0.54 & 2.63 & 3.84 \\
\hline & & $5.1 \%$ & -200 & 531 & 331 & 0.60 & 2.76 & 4.08 \\
\hline
\end{tabular}


Hyytiäinen, K. et al. An integrated simulation model for agricultural nutrient abatement

proportion. However, it should be noted that the benefits and costs are shown for Finland only.

Profitable environmental investments are indicated in bold for both decision criteria in Table 4. N one of the al ternative measures become economically profitable if Finland makes plans to reduce land loads alone and the benefit estimates are based on coastal population only. Reductions in P load from Finnish agriculture become rational only if the neighboring countries are committed to similar reductions and if the benefit estimate is based on a large array of ecosystem services such as that included in the meta-analysis. A large reduction in P load (30\%) gives the highest NPV for interest rates of $2.6 \%$ or larger. However, an environmental project aiming at a smaller reduction in $\mathrm{P}$ load $(16 \%)$ is likely to be more competitive with other public projects due to its higher $B C$.

$A n$ increase in the abatement target tends to widen the probability distribution of NPVs. For example, when assuming joint international effort in abatement, using meta-analysis data for the coastal population and applying a $5.1 \%$ rate of interest (the $15^{\text {th }}$ row in Table 4 ), the standard deviation of NPVs are 11 and 19 million euros for $P 16$ and P30, respectively. Thus, accounting for annual variation in land loads increases the financial risk of larger investments in abatement, but does not al ter the ranking of preferred abatement levels when the selection is based on expected NPV.

Table 4 also illustrates the effect of the population considered. I $n$ addition to the estimates for the adult population living on the coast (2.15 million), meta-analysis benefit estimates are derived for the total adult population in Finland (4.2 million). The latter assume that all Finns appreciate the benefits of the recreation and ecosystem services of the $B$ altic Sea in a similar manner irrespective of their place of residence. Where this is the case, national investments in improving water quality clearly become more profitable. A smaller reduction in $\mathrm{P}$ load (16\%) becomes beneficial for Finland even if its neighbors do not participate in abatement. A larger reduction in $\mathrm{P}$ load (30\%) becomes relatively more attractive if the country's neighbors are committed to similar reductions. However, neither a $16 \%$ nor $30 \%$ reduction in $\mathrm{N}$ (not shown) turns out to be economically attractive even when using the highest damage estimate. This reflects the higher costs of $\mathrm{N}$ abatement technologies. The NPVs and BCs for a $30 \%$ reduction in $\mathrm{N}$ are lower than those for a $16 \%$ reduction in $\mathrm{N}$ for all parameter values and are thus not reported.

The valuation functions (Fig. 3) and time paths of abatement benefits (Fig. 5) determine how changes in the rate of interest affect the profitability of an environmental investment. With travel cost data, the expected benefits from abatement tend to increase with time (Fig. 5). As a consequence, investments in water qual ity become relatively more profitable at lower rates of interest. In contrast, meta-analysis data indicate that the expected benefits from nutrient abatement will be highest over the first decades and gradually decrease thereafter (Fig. 5), a trend attributable to the damage function being sigmoidal with respect to changes in water clarity (Fig. 3b). As a consequence, environmental investments in water quality tend to be more profitable at higher rates of interest (Table 4).

The $\mathrm{N}$ and $\mathrm{P}$ concentrations of the Baltic Proper are important determinants of the nutrient budgets of the other basins in the northern Baltic Sea due to the extensive exchange of water. The annual variation and the trends in concentrations of the largest basin reflect the land loads from the Baltic and Central European countries - Poland in particular - and occasional "salt pulses" from the A tlantic Ocean. Table 5 shows how assumptions about the future development of $\mathrm{N}$ and $\mathrm{P}$ concentrations in the Baltic Proper affect the profitability of environmental projects in Finland. Parameter $\beta$ represents the rate of change, and parameter $\alpha$ the proportional increase in nutrient concentrations when comparing the present level and the long-term equilibrium. A ccording to the results, investments in reducing the nutrient load from the watersheds of the northern Baltic Sea become economically more attractive, the lower the long-term average nutrient concentration of the Baltic Proper is. In addition, the slower the rate at which concentrations increase in the Baltic Proper, the more profitable are the investments in water qual ity in Finland.

The results regarding the feasibility of environmental investments in water quality have thus far 
Vol. 18 (2009): 440-459.

Table 5. The effects on the profitability of environmental investment in Finland of assumptions regarding the long-term steady-state nutrient concentrations in the Baltic Proper $(\alpha)$ and the rate of change $(\beta)$

\begin{tabular}{|c|c|c|c|c|c|c|c|}
\hline \multirow[b]{2}{*}{$\alpha$} & \multirow[b]{2}{*}{$\beta$} & \multicolumn{3}{|c|}{ Net present value, million $€$} & \multicolumn{3}{|c|}{ Benefit-cost ratio } \\
\hline & & N 16 & P30 & P16 & N 16 & P30 & P16 \\
\hline-0.1 & 0.01 & -296 & 214 & 175 & 0.40 & 1.70 & 2.60 \\
\hline-0.1 & 0.03 & -293 & 213 & 176 & 0.41 & 1.70 & 2.61 \\
\hline-0.1 & 0.05 & -291 & 214 & 177 & 0.41 & 1.70 & 2.62 \\
\hline 0.3 & 0.01 & -317 & 184 & 153 & 0.36 & 1.60 & 2.40 \\
\hline 0.3 & 0.03 & -345 & 124 & 117 & 0.31 & 1.41 & 2.08 \\
\hline 0.3 & 0.05 & -361 & 84 & 95 & 0.27 & 1.27 & 1.85 \\
\hline 0.7 & 0.01 & -344 & 123 & 117 & 0.31 & 1.40 & 2.07 \\
\hline 0.7 & 0.03 & -393 & -8 & 46 & 0.21 & 0.97 & 1.42 \\
\hline 0.7 & 0.05 & -416 & -70 & 13 & 0.16 & 0.77 & 1.12 \\
\hline
\end{tabular}

Assumptions: Valuation is based on meta-analysis data and the coastal adult population. All countries in the northern Baltic Sea (Sweden, Finland, Russia and Estonia) participate in abatement.

Table 6. Cost-benefit analysis of abatement investments by basin

\begin{tabular}{|c|c|c|c|c|c|c|c|c|}
\hline \multirow{2}{*}{$\begin{array}{l}\text { International } \\
\text { involvement }\end{array}$} & \multirow{2}{*}{$\begin{array}{l}\text { valuation } \\
\text { approach }\end{array}$} & \multirow[b]{2}{*}{ Basin } & \multicolumn{3}{|c|}{ Expected NPV, million $€$} & \multicolumn{3}{|c|}{ Benefit-cost ratio } \\
\hline & & & N 16 & P30 & P16 & N 16 & P30 & P16 \\
\hline \multirow[t]{3}{*}{ Finland only } & \multirow[t]{3}{*}{ Travel cost } & BB & -212 & -101 & -30 & 0.03 & 0.24 & 0.36 \\
\hline & & BS & -188 & -112 & -38 & 0.03 & 0.06 & 0.10 \\
\hline & & GoF & -82 & -48 & -16 & 0.03 & 0.08 & 0.13 \\
\hline \multirow[t]{3}{*}{ Finland only } & \multirow[t]{3}{*}{ M eta-analysis } & $B B$ & -194 & -5 & 19 & 0.11 & 0.95 & 1.37 \\
\hline & & BS & -178 & -95 & -29 & 0.08 & 0.20 & 0.31 \\
\hline & & GoF & -75 & -37 & -10 & 0.10 & 0.29 & 0.46 \\
\hline & \multirow[t]{3}{*}{ Travel cost } & BB & -208 & -81 & -20 & 0.05 & 0.39 & 0.59 \\
\hline \multirow[t]{2}{*}{ Russia, Estonia } & & BS & -184 & -107 & -36 & 0.05 & 0.10 & 0.17 \\
\hline & & GoF & -59 & -1 & 10 & 0.29 & 0.98 & 1.52 \\
\hline Finland, Sweden & \multirow[t]{3}{*}{ M eta-analysis } & $B B$ & -179 & 80 & 62 & 0.18 & 1.59 & 2.28 \\
\hline \multirow[t]{2}{*}{ Russia, Estonia } & & $B S$ & -165 & -79 & -20 & 0.15 & 0.34 & 0.53 \\
\hline & & GoF & 0 & 127 & 77 & 0.99 & 3.41 & 5.10 \\
\hline
\end{tabular}

Assumptions: Valuation is based on the coastal population only.

been presented for the national level. In Table 6 , the NPVs and the BCs are shown by basin when the same abatement measure is applied uniformly in all regions (note that the unit costs of abatement are assumed to be the same for all regions). Table 6 suggests that nutrient abatement yiel ds much higher returns for areas adjacent to the Bothnian Bay (BB) and the Gulf of Finland (GoF) than for the coastline of the Bothnian Sea (BS). Reduction of nutrient loads from agriculture is an effective means to improve the quality of the B othnian B ay because land loads from the Finnish rivers represent a high proportion of the total nutrient inputs. In addition, the exchange of water with the other basins is small. 
Hyytiäinen, K. et al. An integrated simulation model for agricultural nutrient abatement

On the other hand, the size of the coastal population (and hence the benefit) is relatively small along the B othnian Bay. In the Gulf of Finland, land loads from Finnish rivers represent only a minute share of the total nutrient loads, but the relative size of the coastal population is much higher, yielding greater benefits for abatement. In the case of the Bothnian Sea, the relative size of the population and the share of nutrient loads from Finnish rivers are both small and the environmental investment in water quality does not prove profitable. If Finland is the only country investing in nutrient abatement, investments in the Bothnian Bay give the highest return. However, if the neighboring countries are also committed to abatement, the highest returns are realized for the Gulf of Finland.

There are large differences between the basins in how national and international nutrient abatement efforts might affect the water quality. Our simulations indicate that it is possible to improve the mean sight depth of the Bothnian Bay by 3-15 $\mathrm{cm}$ through investment in reducing Finnish agricultural nutrient runoff. However, joint efforts between Sweden and Finland could improve the water clarity of the Bay by up to $30 \mathrm{~cm}$ over the basel ine development. In the Gulf of Finland, Finnish investments would improve water quality by less than $1 \mathrm{~cm}$. This improvement in water clarity and the consequent benefits would be negligible compared to the weather-induced annual variation in water clarity. H ow ever, if neighboring countries, including R ussia and Estonia, were to participate in the abatement, the mean clarity of the Gulf could be improved by up to $7 \mathrm{~cm}$ over the baseline development. The simulations demonstrate the importance of joint efforts in combating eutrophication.

\section{Discussion and conclusions}

We have presented a stochastic simulation model capturing the ecological and economic features of eutrophication that are necessary for the eval uation and design of nutrient abatement measures. $\mathrm{N}$ onpoint source pollution from agriculture is modeled using stochastic nutrient loads, which fluctuate according to w eather shocks. A nnual variation in land loads leads to variation in nutrient concentrations of the sea basins and consequently causes variation in the temporal distribution of benefits from nutrient abatement (see Fig. 5). Further development of this model feature is particularly important in future work as climate change is likely to increase the variance in land loads and al gal grow th conditions, and may thus increase the damage substantially.

The results suggest that national investments in reducing the nutrient load from Finnish agricultural lands become profitable only if Finland's neighbors in the northern Baltic Sea commit themselves to similar reductions. This result is well in line with earlier studies that have investigated optimal allocation of abatement activities betw een countries. Investments in sew age treatment plants and reductions in other point sources (e.g. Turner et al. 1999) or non-point sources (Elofsson 2003) in the Russian and Polish coastal zones typically turn out to be the most profitable means to improve the overall state of the Baltic Sea.

The critical factors affecting the profitability of investment in abatement are the costs of the best nutrient abatement activities, the effectiveness of nutrient abatement on seawater quality and the proportion of the population benefiting from improved recreation and ecosystem services. Our results suggest that Finnish investments in agricultural abatement would be most profitable in the case of either the B othnian Bay, where abatement would have a strong effect despite the small population, or the Gulf of Finland, where abatement would be less effective but the population density is higher. These results are somewhat surprising, given that the focus of the Baltic Sea policy has not been the B othnian Bay, but they are understandable from the national point of view. First, nutrient abatement is effective because Finnish rivers represent a high proportion of the total nutrient inputs. Second, without additional nutrient abatement water quality in the Bothnian Bay will deteriorate (see Fig. 4), which would lead to increasing damage and economic losses in the near future.

Contrary to the assumption in our basin-oriented model, ecosystem values are not evenly distributed 
Vol. 18 (2009): 440-459.

over the entire sea basin. For example, recreational use of the sea is highly concentrated in coastal waters. In this light, even though Finnish investments in improving the overall state of the B othnian Sea would not be profitable according to our computations, nutrient abatement may be economically justified in critical watersheds and rivers discharging their waters into the recreational ly most important marine areas. For example, Pitkänen et al. (2007) illustrate that al gae biomass in the A rchipelago Sea could be substantially reduced by reducing the nutrient load from Finnish rivers al one.

The abatement cost estimates contain detailed information on the measures available to Finnish agriculture. Although the simulated costs rely on parameters from a single Finnish watershed, the framework applied can be spatially extended to any other Finnish watershed or combined with national average parameters. The current parameterization would lead to a reduction in $P$ through changes in crop cultivation methods on both dairy and cereal farms. Cost-efficient $\mathrm{N}$ reduction turned out to be more expensive than $\mathrm{P}$ reduction. According to the results, $\mathrm{N}$ reductions could mainly be achieved by reducing fertilization. The optimal combination of abatement means, as w ell as the result that relative reductions in $\mathrm{P}$ loads are less expensive than reductions in N loads, are in line with corresponding Swedish studies (Brady 2003, Elofsson 2003).

The baseline in the abatement cost calculations includes subsidies for agricul tural production, with the exception of the environmental subsidy system. Including all the effects of the environmental subsidy system would require even more detailed modeling and introduce a bias in favor of a particular measure into the results on abatement costs. Hence, the abatement costs should be interpreted with care: the baseline optimal solution does not have a one-to-one correspondence with the current agricultural practices in Finland. Furthermore, the abatement cost analysis would benefit from a dynamic element that incorporates the $P$ stock in soil and the future structural trends of agriculture into the abatement cost calculation.

The analysis conducted in this study represents the first attempt to link benefit functions to a dynamic modeling framework for the entire Finnish coastline. We provide two distinct approaches for valuing the changes in Secchi depth and thus provide novel estimates for the monetary effects of eutrophication in the B altic Sea. Interestingly, the value functions differ in their functional forms and the results are sensitive to the approach chosen.

Our estimated transfer function between nutrient concentrations and Secchi depth is simple by nature. It assumes that changes in basin-level nutrient concentrations are uniform across the basin. While this assumption is an approximate one, it is currently the best available approach to render the changes in nutrient loads and recreation behavior commensurate. Better hydrological models with higher spatial resolution are required in the future to better understand the effects of nutrients at the coastal level, where most of the recreation takes place.

The framework developed in this paper provides a wide range of possibilities to develop the analysis further. The valuation of the effects of eutrophication could be developed to obtain more comprehensive benefit estimates. At this stage, the value functions presented reflect merely part of the total economic value of the Baltic marine ecosystem services; the travel cost estimates represent a conservative lower bound to the value of water recreation in Finland, and the meta-analysis provides an estimate of marine-related use and nonuse values. It is also worth noting that the valuation of the benefits for minor and extreme changes is challenging, because it is based on people's perceptions and experiences. Thus, the value functions constructed are less reliable for very small and very large changes in the sight depth in the Baltic Sea, which is an issue requiring further study.

The analysis would benefit from more specific descriptions of the causes and effects of eutrophication, including spatial, temporal and sociodemographic distributions of water conservation costs and benefits. In particular, it is essential to identify the population groups that perceive high water quality as extremely or even immeasurably important. By identifying these groups, we may attempt to find ways to compensate them for their Iosses. The simulation model could be developed by increasing the detail in the description of bio- 


\section{Hyytiäinen, K. et al. An integrated simulation model for agricultural nutrient abatement}

geochemical processes (Pitkänen et al 2007, Savchuk and Wulff 2009), and establishing the causal relationship between nutrient concentrations and damage.

The focus in this study has been on the agricul tural abatement costs. The perspective could be widened to other polluting sources, such as forestry, municipal wastewaters and urban settlements. In practice, the temporal and spatial boundaries of the analysis present challenges when estimating the policy effects (e.g. Hanley 2001). The incompleteness of an analysis always leaves room for political considerations in the evaluation of omitted effects. However, an extensive cost-benefit analysis, such as the one presented in this study, provides decision-makers with systematically organized information on the benefits and costs of an environmental project.

Acknowledgements. The model was developed in a preproject study which assessed the possibilities for economic analysis of the protection of the Baltic Sea. The project was financed by four Finnish ministries (the Ministry of A griculture and Forestry, the M inistry of Education, the $M$ inistry of the Environment, and the M inistry of Transport and Communications). We gratefully acknowledge our colleagues at M TT A grifood R esearch Finland, the Finnish Environment Institute, and the Fisheries and Environmental $M$ anagement $G$ roup of the University of Helsinki for feedback and comments on our prototype model. We also thank Anita Ojala at MTT Economic Research for her help in the technical editing of this paper.

\section{References}

Ahtiainen, H. 2009. Valuing international marine resources: A meta-analysis on the Baltic Sea. MTT Discussion Papers 1/2009. Available on the internet: http://www.mtt.fi/english/publications/dp/2009/ DP2009_1.pdf

Baltic Nest Institute. 2008. Nest, an information environment for decision support system. Cited: 20.10.2008. Available on the internet: http://nest.su.se/nest/.

Beaumont, N.J., Austen, M.C., Atkins, J.P., Burdon, D., Degraer, S., Dentinho, T.P., Derous, S., Holm, P., Horton, T., van lerland, E., Marboe, A.H., Starkey, D.J., Townsend, M. \& Zarzycki, T. 2007. Identification, definition and quantification of goods and services provided by marine biodiversity: Implications for the ecosystem approach.
Marine Pollution Bulletin 54: 253-265.

Brady, M. 2003. The Relative Cost-efficiency of Arable Nitrogen Management in Sweden. Ecological Economics 47: 53-70.

Byström, O. 2000. The Replacement Value of Wetlands in Sweden. Environmental and Resource Economics 16: $347-362$.

Egan, K.J., Herriges, J.A., Kling, C.L. \& Downing, J.A. 2009. Valuing Water Quality as a Function of Water Quality Measures. American Journal of Agricultural Economics 91: 106-123.

Elofsson, K. 2003. Cost-effective reductions of stochastic agricultural loads to the Baltic Sea. Ecological Economics 47: 13-31.

Finnish Government. 2006. Water Protection Targets 2015. (in Finnish). Available on the internet: http://www.ymparisto. fi/download .asp?contentid $=59919 \&$ lan $=\mathrm{fi}$

Fishman, G.S. 1995. Monte Carlo: Concepts, Algorithms, and Applications. Springer, N.Y. 698 p.

Government of the Russian Federation. 2007. Russia's Rural Development Program. Agricultural Development and Regulation of Agricultural Produce, Raw Materials and Foods for 2008-2012. Decision no. 446, July 14, 2007. (Available by request from the Ministry of Agriculture and Forestry of Finland)

Gren, I.-M. 2001. International Versus National Actions Against Nitrogen Pollution of the Baltic Sea. Environmental and Resource Economics 20: 41-59.

Gren, I-M. 2008. Adaptation and mitigation strategies for controlling stochastic water pollution: An application to the Baltic Sea. Ecological Economics 66: 337-347.

Gren, I.-M., Destouni, G. \& Scharin, H. 2000. Cost effective management of stochastic coastal water pollution. Environmental Modeling and Assessment 5: 193-203.

Gren, I-M., Lindahl, O. \& Lindqvist, M. 2009. Values of mussel farming for combating eutrophication: An application to the Baltic Sea. Ecological Engineering 35: 935-945.

Hanley, N. 2001. Cost-benefit analysis and environmental policymaking. Environment and Planning C: Government and Policy 19: 103-118.

Hart, R. \& Brady, M. 2002. Nitrogen in the Baltic Sea - Policy Implications of Stock Effects. Journal of Environmental Management 66: 91-103.

Helcom 2005. Nutrient pollution to the Baltic Sea in 2000. Baltic Sea environment proceedings 100. Available on the internet: http://www.helcom.fi/publications/bsep/ en_GB/bseplist/

Helcom 2007. Baltic Sea Action Plan. 101 p. Available on the internet: http://www.helcom.fi/stc/files/BSAP/ BSAP Final.pdf

Helin, J. 2009. Kotieläintalouden ravinnekierron ympäristötaloudellinen optimointi: Aluemalli maidon- ja viljantuotantoon erikoistuneille tiloille. Maa-ja elintarviketalous. In press. (in Finnish).

Helin, J., Laukkanen, M. \& Koikkalainen, K. 2006. Abatement costs for agricultural nitrogen and phosphorus loads: a case study of crop farming in south-western Finland. Agricultural and Food Science 15: 351-374.

Kadin, M. 2009. Trends and scenarios exemplifying the future of the Baltic Sea and Skagerrak. The Swedish Environmental Protection Agency. In press.

Kahneman, D., Knetsch, J. L. \& Thaler, R. H. 1991. The 


\section{AGRICULTURAL AND FOOD SCIENCE}

Vol. 18 (2009): 440-459.

Endowment Effect, Loss Aversion and Status Quo Bias. Journal of Economic Perspectives 5: 193-206.

Lappalainen, A. 2002. The Effects of Recent Eutrophication on Freshwater Fish Communities and Fishery on the Northern Coast of the Gulf of Finland, Baltic Sea. Academic Dissertation. University of Helsinki, Department of Limnology and Environmental Protection and Finnish Game and Fisheries Research Institute.

Laukkanen, M. \& Huhtala, A. 2008. Optimal management of a eutrophied coastal ecosystem: balancing agricultural and municipal abatement measures. Environmental and Resource Economics 39: 139-159.

Markowska, A. \& Zylicz, T. 1999. Costing an international public good: the case of the Baltic Sea. Ecological Economics 30: 301-316.

Michael, H. J., Boyle, K. J. \& Bouchard, R. 2000. Does the Measurement of Environmental Quality Affect Implicit Prices Estimated from Hedonic Models? Land Economics 76: 283-298.

MMM. 2008. Maa- ja metsätalousministeriö: Pitkän aikavälin skenaariot - maatalous, metsätalous ja maankäyttö. Muistio 20.2.2008. (in Finnish). 28 p. Available on the internet: http://www.mmm.fi/attachments/ ymparisto/5xVI1MhbH/MMM-35768-v1-MMM_pitkan_ aikavalin_skenaariot_-_maatalous__metsatalous_ja_maankaytto_2.pdf

Ollikainen, M. \& Honkatukia, J. 2001. Towards Efficient Pollution Control in the Baltic Sea: An Anatomy of Current Failure with Suggestions for Change. Ambio 30: 245-253.

Pitkänen, H., Kiirikki, M., Savchuk, O.P., Räike, A., Korpinen, P. \& Wulff, F. 2007. Searching efficient protection strategies for the eutrophied Gulf of Finland: the combined use of $1 D$ and $3 D$ modeling in assessing longterm state scenarios with high spatial resolution. Ambio 36: 272-279.

Rekolainen, S. \& Posch, M. 1993. Adapting the CREAMS model for Finnish conditions. Nordic-Hydrology 24: 309-322.

Savchuk, O.P. 2005. Resolving the Baltic Sea into seven subbasins: $N$ and $P$ budgets for 1991-1999. Journal of Marine Systems 56:1-15.

Savchuk, O.P. \& Wulff, F. 2007. Modeling the Baltic Sea Eutrophication in a Decision Support System. Ambio 36: 141-148.

Savchuk, O.P. \& Wulff, F. 2009. Long-term modeling of large-scale nutrient cycles in the entire Baltic Sea. Hydrobiologia (published online 23 April 2009).

Simmelsgaard, S. \& Djurhuus, J. 1998. An empirical model for estimating nitrate leaching as affected by crop type and the long-term fertilizer rate. Soil Use and Management 14: 37-43.

Soutukorva, $\AA$. 2005 . The value of improved water quality - A random utility model of recreation in the Stockholm archipelago. Beijer International Institute of Ecological Economics. The Royal Swedish Academy of Sciences, Stockholm. Available on the internet: http://www.beijer.
kva.se/PDF/49545339_artdisc135.pdf

Statistics Estonia. 2008. Agricultural Statistics. Cited: 8.6.2009. Available on the internet: http://pub.stat.ee/ px-web.2001/I_Databas/Economy/01AGRICULTURE/ O1AGRICULTURE.asp

Stern, N. 2007. The Economics of Climate Change: The Stern review. Cambridge University Press.

Toivonen, A.-L., Roth, E., Navrud, S., Gudbergsson, G., Appelblad, H., Bengtsson, B. \&Tuunainen, P. 2004 The Economic Value of Recreational Fisheries in Nordic Countries. Fisheries Management and Ecology 11: 1-14.

Turner, R.K. 2007. Limits to CBA in UK and European environmental policy: retrospects and future prospects. Environmental and Resource Economics 37: 253-269.

Turner, R.K., Georgiou, S., Gren, I., Wulff, F., Barrett, S., Söderqvist, T., Bateman, I.J., Folke, C., Langaas, S., Zylicz, T., Mäler, K-G. \& Markowska, A. 1999. Managing nutrient fluxes and pollution in the Baltic: an interdisciplinary simulation study. Ecological Economics 30: 333-352.

Turtola, E. \& Paajanen, A. 1995. Influence of improved subsurface drainage on phosphorus losses and nitrogen leaching from a heavy clay soil. Agricultural Water Management 28: 295-310.

Tversky, A. \& Kahneman, D. 1991. Loss Aversion in Riskless Choice: A Reference-Dependent Model. Quarterly Journal of Economics 106: 1039-1061.

Uusitalo, R. \& Jansson, H. 2002. Dissolved reactive phosphorus in runoff assessed by soil extraction with an acetate buffer. Agricultural and Food Science in Finland 11: 343-353.

Uusitalo, R., Turtola, E., Puustinen, M., Paasonen-Kivekäs, M. \& Uusi-Kämppä, J. 2003. Contribution of particulate phosphorus to runoff phosphorus bioavailability. Journal of Environmental Quality 32: 2007-2016.

Vesterinen, J., Pouta, E., Huhtala, A. \& Neuvonen, M. 2009. Impacts of changes in water quality on recreation behavior and benefits in Finland. Under review.

Worm, B., Barbier, E., Beaumont, N., Duffy, E., Folke, C., Halpern, B., Jackson, J., Lotze, H., Micheli, F., Palumbi,S.R., Sala, E., Selkoe, K.A., Stachowicz, J.J. \& Watson, R. 2006. Impacts of Biodiversity Loss on Ocean Ecosystem Services. Science 314: 787-790.

Wulff, F., Bonsdorff, E., Gren, I-M., Johansson, S. \& Stigebrandt, A. 2001. Giving Advice on Cost Effective Measures for a Cleaner Baltic Sea: A Challenge for Science. Ambio 30: 254-259.

Yearbook of Farm Statistics. 1983. National Board of Agriculture. $286 \mathrm{p}$.

Yearbook of Farm Statistics. 1992/93. Information Centre of the Ministry of Agriculture and Forestry.

Yearbook of Farm Statistics. 2000. Information Centre of the Ministry of Agriculture and Forestry.

Yearbook of Farm Statistics. 2007. Information Centre of the Ministry of Agriculture and Forestry. 
Hyytiäinen, K. et al. An integrated simulation model for agricultural nutrient abatement

\section{Appendix}

Appendix 1. Parameter values

Eqs. [1]-[3]: Nutrient balance (source: Baltic Nest Institute 2008)

\begin{tabular}{|c|c|c|c|c|c|c|c|c|c|c|c|c|c|c|}
\hline \multirow[t]{2}{*}{$\begin{array}{l}\text { Basin, } \\
i=1 \ldots 4\end{array}$} & \multicolumn{2}{|c|}{$\begin{array}{l}\text { A tmospheric } \\
\text { deposition } \\
\text { (ton) }\end{array}$} & \multirow{2}{*}{$\begin{array}{c}\text { Nitrogen } \\
\text { fixation } \\
\text { (ton) } \\
\mathrm{F}_{\mathrm{i}}\end{array}$} & \multicolumn{2}{|c|}{$\begin{array}{l}\text { Burial } \\
\text { (ton) }\end{array}$} & \multirow{2}{*}{$\begin{array}{c}\text { Denitrifi- } \\
\text { cation } \\
\text { (ton) } \\
D_{i}\end{array}$} & \multirow{2}{*}{$\begin{array}{l}\text { Intern. } \\
\text { loading } \\
\text { of } P \\
\text { (ton) } \\
\mathrm{I}_{\mathrm{i}}\end{array}$} & \multicolumn{2}{|c|}{$\begin{array}{l}\text { Initial } \\
\text { concen- } \\
\text { tration } \\
\left(\mu \mathrm{g} \mathrm{I}^{-1}\right)\end{array}$} & \multirow{2}{*}{$\begin{array}{c}\text { W ater } \\
\text { volume } \\
\left(\mathrm{km}^{3}\right) \\
\mathrm{V}_{\mathrm{i}}\end{array}$} & \multicolumn{4}{|c|}{$\begin{array}{l}\text { A nnual flows } \\
\text { of water from } \\
\text { basin } \mathrm{i}\left(\mathrm{km}^{3}\right) \text { to: }\end{array}$} \\
\hline & $\mathrm{A}_{i}{ }^{N}$ & $A_{i}{ }^{p}$ & & $B_{i}^{N}$ & $\mathrm{~B}_{i}^{\mathrm{P}}$ & & & $C_{i 0}^{N}$ & $C_{i 0}^{P}$ & & B B & BS & GoF & $\mathrm{BP}$ \\
\hline $1(\mathrm{BB})$ & 10584 & 562 & 0 & 3964 & 4086 & 16987 & 0 & 298 & 6.2 & 1441 & 0 & 290 & 0 & 0 \\
\hline $2(\mathrm{BS})$ & 32636 & 1178 & 17574 & 10674 & 8461 & 88063 & 400 & 262 & 16 & 4485 & 173 & 0 & 0 & 1237 \\
\hline $3(\mathrm{GoF})$ & 15394 & 445 & 18073 & 9911 & 4118 & 64421 & 2800 & 343 & 25 & 1100 & 0 & 0 & 0 & 554 \\
\hline $4(\mathrm{BP})$ & & & & & & & & 272 & 25 & & 0 & 1009 & 435 & 0 \\
\hline
\end{tabular}

$\mathrm{BB}=\mathrm{B}$ othnian $\mathrm{B}$ ay, $\mathrm{BS}=\mathrm{B}$ othnian Sea, $\mathrm{G}$ oF $=$ Gulf of Finland, B P=B altic Proper

Eq. [4]: Development of nutrient concentrations in the B altic Proper (sources: Savchuk 2005, expert opinion):

\begin{tabular}{|l|l|l|}
\hline & $\mathrm{N}$ & $\mathrm{P}$ \\
\hline$\alpha$ & 0.3 & 0.3 \\
\hline$\beta$ & 0.03 & 0.03 \\
\hline$\sigma$ & 0.05 & 0.135 \\
\hline
\end{tabular}

Eq. [6]: Shares of agriculture in total land loads (source: Helcom 2005)

\begin{tabular}{|l|l|l|}
\hline basin i & $N, \tau_{y}$ & $P, \tau_{y}$ \\
\hline $1(B B)$ & $0.417(y=1,2)$ & $0.382(y=8,9)$ \\
\hline $2(B S)$ & $0.438(y=3,4)$ & $0.399(y=10,11)$ \\
\hline $3($ GoF $)$ & $0.359(y=5,6,7)$ & $0.443(y=12,13,14)$ \\
\hline
\end{tabular}

Eqs. [6]-[8]: Nutrient reductions, $\phi_{y}$, and unit costs, $c_{-}$abat $t_{h}$ (in parentheses), for different abatement measures (h) (sources: Helin et al. 2006, Helin 2009)

\begin{tabular}{|l|l|l|l|l|}
\hline $\begin{array}{l}\text { A batement } \\
\text { M easure }\end{array}$ & $\mathrm{h}=2(\mathrm{~N} \mathrm{30})$ & $\mathrm{h}=3(\mathrm{~N} \mathrm{16})$ & $\mathrm{h}=4(\mathrm{P30})$ & $\mathrm{h}=5(\mathrm{P} 16)$ \\
$\phi_{\mathrm{y}}, \mathrm{y}=1, \ldots, 7$ & $\phi_{\mathrm{y}}, \mathrm{y}=1, \ldots, 7$ & $\phi_{\mathrm{y}}, \mathrm{y}=8, \ldots, 14$ & $\phi_{\mathrm{y}}, \mathrm{y}=8, \ldots, 14$ \\
\hline $\mathrm{N}$ & $0.30\left(13.70 € \mathrm{~kg}^{-1}\right)$ & $0.16\left(5.70 € \mathrm{~kg}^{-1}\right)$ & 0.02 & 0.02 \\
\hline $\mathrm{P}$ & 0.035 & 0.035 & $0.30\left(32.91 € \mathrm{~kg}^{-1}\right)$ & $0.16\left(22.04 € \mathrm{~kg}^{-1}\right)$ \\
\hline
\end{tabular}

Eq. [9] Water clarity (parameters derived from the data in V esterinen et al. 2009):

\begin{tabular}{|l|l|l|l|l|l|l|}
\hline basin i & $\eta_{\mathrm{i}}$ & $\kappa_{1}$ & $\kappa_{2}$ & $\kappa_{3}$ & $\kappa_{4}$ & $\kappa_{5}$ \\
\hline $1(\mathrm{BB})$ & 8.099 & -1.401 & -0.506 & 0.023 & 0 & 0.019 \\
\hline $2(\mathrm{BS})$ & 15.602 & -1.82 & -1.612 & 0.052 & 0.032 & 0.025 \\
\hline $3(\mathrm{GoF})$ & 11.146 & -1.254 & -0.809 & 0.007 & -0.042 & 0.031 \\
\hline
\end{tabular}

temp $=20$, depth $=15$

Eq. [10]: V alue function based on recreation possibilities (V esterinen et al. 2009)

\begin{tabular}{|l|l|l|l|}
\hline basin i & $\delta_{1 \mathrm{i}}$ & $\delta_{2 \mathrm{i}}$ & $\delta_{3 \mathrm{i}}$ \\
\hline $1(\mathrm{BB})$ & -146.4 & 199.1 & 1.06 \\
\hline $2(\mathrm{BS})$ & -182.3 & 244.1 & 0.959 \\
\hline $3(\mathrm{GoF})$ & -397.1 & 485.9 & 0.448 \\
\hline
\end{tabular}

Eq. [11]: V alue function based on meta-analysis and adult coastal population (A htiainen 2009)

\begin{tabular}{|l|l|l|l|l|}
\hline basin i & $\vartheta_{1 \mathrm{i}}$ & $\vartheta_{2 \mathrm{i}}$ & $\vartheta_{3 \mathrm{i}}$ & $\vartheta_{4 \mathrm{i}}$ \\
\hline $1(\mathrm{BB})$ & -42.9 & 73.4 & 2.89 & 0.303 \\
\hline $2(\mathrm{BS})$ & -53.4 & 91.4 & 2.77 & 0.291 \\
\hline $3(\mathrm{GoF})$ & -116.6 & 199.4 & 2.01 & 0.211 \\
\hline
\end{tabular}


Vol. 18 (2009): 440-459.

\section{SELOSTE}

\section{Stokastinen simulointimalli maatalouden ravinnekuormituksen vähentämistoimien arvioimiseksi}

Kari Hyytiäinen, Heini A htiainen, Jaakko Heikkilä, Janne Helin, A nni Huhtala, A ntti Iho, K auko K oikkalainen, A ntti M iettinen, Eija Pouta ja J anne Vesterinen

MTT Taloustutkimus

Tässä tutkimuksessa esitetään malli, jonka avulla voidaan arvioida maatalouden ravinnekuormituksen vähentämistoimia kansallisesta näkökulmasta. Stokastinen simulointimalli yhdistää typen ja fosforin kertymisen dynamiikan Suomen rannikkoalueen al taissa, maal ta ja muista lähteistä tul evan ravinnekuormituksen, ravinteiden vähentämisestä koituvat hyödyt (virkistys- ja ekosysteemipalveluiden arvojen muodossa) sekä maatalouden kuormituksen vähentämisen kustannukset. Tutkimuksen tarkoituksena on esittää mallin yleisrakenne sekä havainnollistaa sen käyttökelpoisuutta ja hyödynnettävyyttä alustavien mallilaskelmien avulla. Mallin rakenne on joustava: mallin ekologisia ja taloustieteellisiä osia voidaan kehittää erikseen myös jatkossa. Mallin herkkyy- sanalyysin tulokset osoittavat, että ravinteiden vähentäminen Suomen maatal oudessa on kannattavaa ainoastaan silloin, kun naapurimaat pohjoisella I tämerellä ryhtyvät vastaaviin kuormituksen vähentämistoimiin. Mallin mukaan suurimmat tuotot suomalaisista investoinneista vedenlaadun parantamiseksi syntyvät Perämerellä ja Suomenlahdella - pienimmät Selkämerellä. M aataloudesta peräisin olevan kuormituksen vähentäminen on kannattavaa Perämerellä, koska sinne päätyvän Suomen jokikuormituksen osuus kokonaiskuormituksesta on suuri. Suomenlahdella Suomen osuus kuormituksesta on pieni, mutta vedenlaadun paranemisesta hyötyvän suomalaisen rannikkoväestön määrä on suuri. 